\title{
Literature As Tool for Sustainable Development: A Comparative Literary Analysis of Achebe's Arrow of God and Tahir's the Last Imam
}

\author{
ABUBAKAR MOHAMMED SANI \\ Faculty of Modern Languages and Communication \\ Unversiti Putra, Malaysia \\ E-mail: abusanimoh@yahoo.com
}

Doi:10.7575/aiac.alls.v.5n.3p.206

URL: http://dx.doi.org/10.7575/aiac.alls.v.5n.3p.206
Received: $18 / 04 / 2014$

Accepted: 27/05/2014

\begin{abstract}
This paper aims at a theoretical comparative textual analysis of two novels; Chinua Achebe's Arrow of God (1964) and Ibrahim Tahir's The Last Imam (1984). The focus is on their similarities generally and roles played by the heroes in their different societies as political and religious leaders of the different societies and how their actions and in-actions affect their communities and the polity generally. The paper relates the portrayal these as synonymous to the current political leadership crisis in Nigeria and other African nations. The study demonstrates how this crisis hinders sustainable development in the country and other African countries. They way out of this as possible solutions the turmoil is proffer at the end.
\end{abstract}

Keywords: literature, sustainable development, comparative literacy

\section{Introduction}

Despite the time space between the periods Chinua Achebe's Arrow of God (1964) and Ibrahim Tahir's The Last Imam (1984) were written and their differences in socio-cultural background, I argue that they share so many things in common. Thus, the social and political roles assigned to the heroes of both novels depict their closeness, Ezeulu in Arrow of God (1964) Achebe's third but most fascinating novel and Alhaji Usman in The Last Imam (1984) Ibrahim Tahir's only novel. Therefore, this paper aims to under take a theoretical comparative textual analysis of the two novels which some critics describe as among the most fascinating in Nigerian literary circle.

However, the concern will be on their general similarities but with particular attention to the heroes, Ezeulu in Arrow of God and Alhaji Usman in The Last Imam, respectively. The paper will analyze their roles in their respective societies and how they relate with the members of those communities, the out come of their leadership roles and relate such to the present day leaders and to depicts how they contributes to the political crises in Nigeria. Possible solutions will also be provided. For many critics Achebe's Arrow of God (1964) is describe as his best novel so far and therefore has received several critical analyses far more than Tahir's The Last Imam (1984). This cannot be divorced from the reasons advanced by Bamikunle:

By the time it arrived, (The Last Imam), an outline of critical canon in Nigerian novel had been established into which the novel could not easily fit. Also the publishing in hard cover... did not help its reputation. (2003:3).

Perhaps, if it has been written in Heinemann paper back it would have receives better critical "fortune". Whatsoever, the two novels have many things in common and it is some of those things that this paper intends to expose or demonstrate particularly their socio-political similarities, and relate these themes to the current socio-political situation Nigeria.

The two novels have their settings in theocratic societies, in Achebe's Arrow of God the society is purely traditional where gods are very close to the activities of men, thus exert great control on the activities of men; determining their social activities such as annual cycle of the entire community. While in Tahir's The Last Imam, the community is an Islamic society, here the life is controlled and directed according to Islamic customs and traditions. Both novels portray their societies at point of leadership crisis as it is with the case in Nigeria presently. This happens at the period when the two societies renounce religious idealism in favor of practical political and social exigencies. For instance, in Arrow of God, conflict between the priest of Illu, the reigning god of the village and the community, got to its peak when strict observation of the rules of Illu (the god) spelt ruin for the farm produce of the community, the community abandoned the god, the priest went mad in what the village concludes as a punishment from their god, and a sizeable proportion of the population joined the Christian Church or paid tribute to the Christian God, thus, dealing a total blow to the traditional religion. According to Nnolim, Charles, “... Ezeulu fails himself and Umuaro because he chooses to be blind to the limitations of his powers". (p.214). These attitudes of Ezeulu can be liking to the attitudes of the politicians in 
Nigeria who are elected by their people under a political party but having intoxicated by power abandoned the people and the party and decamp to the a ruling or a bigger party. They also fail to fulfill the campaign promises they made to electorate. These are some of the crises the democratic system in Nigeria is battling with, which is not the case in advanced democracies.

On the other hand, in The Last Imam, Alhaji Usman, the hero, who is identified for his ardent observation of Islamic traditions and customs, against all suggestions and advise, dig the grave under his feet when in pursuing religious purification of the society he begins to preach against social practices in the society upon which the history and culture of the society or Emirate - Bauchi - has been built. These are the issues of "Gwauro", "Nuptial Cycle" and "Bastardy". (Tahir, 1984:196). Consequently, the religion was locked in a pitch battle against politics and the political leaders on one side and the Imam on the other. In spite of the high admiration and respect in which he is held by the people, is quickly removed and replaced by his "noble bastard" half-brother. (p.243), Mallam Shuaibu, who Alhaji Usman the people refers to as "quack" and "inferior" but who because of this is better placed to satisfy the social and political needs of the political leaders of the society. In un-turbaning of Alhaji Usman as the Imam, the Emir states that:

For I have in mind a successor to him, a man as different from him as life is different from death... it is enough that you know that he will be an agreeable Imam, much better suited for the ways of some of us.(p.241).

The incident above depicts exactly what the political leaders in Nigeria do by replacing competent persons with "quacks" in political positions such as ministers, commissioners, special advisers/assistants and even into elective positions. Because the quacks or the persons with shady records will not challenge them rather they will abide by their directives unchallenged. Thus, competent persons are not giving appointments in government today because they may not be used as stooges to perpetrate crimes, therefore quacks are appointed.

Interestingly, the historic periods chosen by the two novelists are somehow similar. Thus, they both choose periods of relative liberalization encouraged by end of century events which militate against strict and rigid observations of religious laws and customs. In Arrow of God we see references to dates in the colonial memories or diaries such as, "1910" and "1919". (pp. 129,135). The events in the novel point to the late 19th century and 20th century colonial history, when the Whiteman had started but had not fully established his administration in the Southern part of Nigeria. And the activities of the Whiteman and what he did to the men of Abame and Umuofia as narrated in Achebe's first novel Things Fall Apart (1958) are referred to in Arrow of God, are adequate to suggest a liberalizing impact on the Igbo culture and society. In a newspaper article Bamikunle Aderemi states that "The impact of the "Things" that had fallen apart was everywhere -church, school and white administration traditional religion is no longer intact". (p.3).

But in The Last Imam there is no any mention of arrival or preference of Whiteman in the novel's setting. The end focus is on the internal history and relationships within the Emirate of Bauchi. However, there are references to the Jihad of Uthman Danfodio, which is responsible for the establishment of the Emirate Alhaji Usman's father tells him that:

\begin{abstract}
...the Jihad of Usman Danfodio came and the Emirs of Hausaland received their flags from Shehu Usman... our Emir in Bauchi at the time heard of them and their great learning and devotion to religion and he invited their leader to become Imam... the Imam has always come from amongst them.(p.12).
\end{abstract}

This thence gives us hints which put the story of Alhaji Usman at the end of the 19th century or the beginning of the 20th century. The Jihad took place from the early part of the 19th century, Alhaji Usman is not the first Imam of Bauchi Emirate. His father, too, is not the first Imam because he frequently talks of his ancestors who were Imams, he speaks to Alhaji Usman about them as we read in the quoted statement above and he continues that "since then, my son the Imam has always come from amongst them. I am Imam today and when I die one of my sons will be Imam after me. Who knows, it may be you" (Ibid). This acts of sit-tight in power or transferring of power from father to son is what is reflecting in our democracy where those elected to serve for a single or two terms desire to change the constitution so as to elongate their tenure. This we see during president Obasanjo's regime who tried to elongate his tenure to third term instead of two terms as specify in the constitution. While in some cases some governors tried to plant their stooges to take-over their seat at the end of their tenure which in most cases leads to political crises. And if this is not check many truncate the system.

Furthermore, central characters, in the two novels, are towering figures, physically, mentally and psychologically. Ezeulu is described for the policemen who were ordered to go and arrest him: "What does he look like?" asked the corporal. $\mathrm{He}$ is as tall as an Iroko tree and his skin is white like the sun. In his youth he was called NwaAnyanwu".(p.153).This striking distinguished figure of Ezeulu is confirmed by captain Winterbottom; "But he was a most impressive figure of a man. He was light in complexion, almost red. One rarely finds people like that now and again amongst Ibos". (p.59).

Similarly, Alhaji Usman is as distinguished in his society. He has a physique that is considered unique:

At twenty-five he stood at six foot three and his physique combined this characteristic Fulani height with a pagan like build whose main asset was the mould after mould of muscle. Then there would stand before him, place their hands on his shoulder and shout heartily "the male's male". (p.29). 
Therefore, it is around these two major characters that represent, each, at a particular time of history of societies, the ideals of their societies, that social and political issues of the two novels are embodied. The central developments of the novels concern the gradual erosion and collapse of the ideals that they represent, ideals that made them more important than ordinary men, in the face of circumstances which require flexibility and fact that their idealism was not capable of their fall is not only the fall of their ideals but also the collapse of the culture and values that were founded on those ideals. Their fall consequently, represent social revolutions and new orientations of communal life in the societies of the novels. On both occasions, the collapse or fall does not lead to death, immediately, though in the case of Ezeulu it led to eventual madness; what is important is that life went by them, by-passed them like debris pushed aside by flood. This could happen to any leader at whatever capacity and in any society, and is like a warning to the leaders in Nigeria.

The two major characters are central or vital to the stories of the two novels. There exist moral-spiritual demands of the rules and regulations of religion in the two novels. In both novels also, religion is the organizing force of culture, social customs and traditions. But the religion turns out to be rigid and inflexible in its demands, often ignoring changing social and cultural circumstances that demand relaxation of the rules. This is the case in both novels, eventually forcing the people to choose between the demands of the God/gods and the needs of their daily existence. Very close to this is to life of the community. The question is; who should have the superior loyalty of the priest in a crisis in which he has to choose between God/gods and the people? The dilemma of the heroes, is the need to choose between God's or god's service and the people's service.

The conflicts between religion and politics in the two books is beautifully dramatized both within the hero-characters in themselves, as well as between them, individually and their communities in both novels a related issue has to do with the relationship between the God/gods and their Servant/Imam. The novel raises the issue about who is in control in the relationship between the heroes and the God/gods that they serve. In Arrow of God, the major issue is who is the "Arrow" in the hand of the other, is it Ezeulu or the god (Ulu)? When Ezeulu tells the people the will of Ulu, whose will is really being transmitted? Is there a clear demarcation between the will and that of the priest? Are there not instances in which the will of the priest determines what will of the gods should that he communicates to the people? Nnolim sums up Ezeulu's character by comparing him with Oedipus,

Ezeulu, as well as Oedipus, bears a fate that rightly belongs to the unjust and the malicious-but neither of the two is unjust or malicious. ...Ezeulu's blindness to the realities of the brittle quality of his position in Umuaro as priest-king is the source of his own tragedy. (p.213).

However, this incident is another clear depiction of the so-called democracy in Nigeria. The politicians do the biding of their so-called god- fathers even if it is at the detriment of the country and its people. They struggle to amass wealth through looting the treasury for their personal greed, that of their party and their god-fathers, having no recourse to the electorates that are responsible to their being in power. These attitudes lead to so many upheavals in the democratic system starting the party level to the wider society and in some cases leads to military intervention, coup d'etat, as we have of recent in Mali. And some cases the politicians hide under the pretence of religion to mislead people.

For instance, in The Last Imam, Alhaji Usman - The Imam, insist in the supremacy of God over believe that God will never create or imposes on his followers that which will create suffering and discomfort to them. The Emir draws his attention when he tells him:

...but I must warm you... this is also the kingdom of men. And the people you lead ordinary men. For them you are a need and when you cease to provide for that need they will abandon you.... (in Zainab, 1998:69).

Later it is discover that the Imam, like the politician in Nigeria, is not really practicing what he is preaching to his followers. His activities make one to doubt if really they are in accordance to the dictate of God, such as his "marital injustice". Then one bound to ask if he, Alhaji Usman, is then an "arrow" in the hand of God or an "arrow" in his own hands. Similarly, the political class in Nigeria manipulates the constitutions to suit their wives and caprices at the detriment of the people which subsequently breeds crisis into the system as we have in the settings of the two novels and even Nigeria presently. As a result, the politicians create antagonists that challenge them and their in-actions and even the government institutions for failing to abide by the principles rule of law enshrine in the constitution.

In a related development, both protagonists in the texts of our study, are practically the most prominent characters, they both create power full antagonists that also contribute to the thematic exploit of the novels. For example, in Arrow of God, Nwaka and Ezedemili happen to be antagonistic to Ezeulu, but Nwaka "is powerful character in his own right. (2003:4). He has an oratorical power which draw attention to him when he speaks, this he displays in several occasions in the novel. (1974:15-17,143-144). And most importantly, is the rigorous challenge of Ezeulu and Ulu (god) by Nwaka, this clearly depicts the lack of supremacy of Ulu, the supreme deity of Umuaro as taken by the community.

This is portrays when Nwaka "threatened" Ulu by reminding him of the fate of another deity that failed his people, "the people of Animta burnt one of their deities and drove away the priest". (1974:28). Because of this statement many people fear for him, expecting that Ulu would punish him. But, "Nwaka survives his rashness. His head did not ache, now did his belly, and he did not grow in the middle of the night". (1974:38-39). And Nwaka celebrates this "victory" with a song by the mask, Oqalanya, at the Idemili festival. With confidence one can assert that the conflict with Nwaka and supporters, Ezedimi and the god Idemili push Ezeulu to excesses that led him to his subsequent ruin. One would be 
right to speculate that Nwaka's taunts might have led Ezeulu to confuse his own voice with that of Ulu and mistakes his own desire of vengeance against Nwaka and Ezedemili for Ulu's avowed desire to establish his supremacy over Idemili. Judging by what happened to Ezeulu, one cannot be sure that it was Ulu who spoke when Ezeulu hears, "Go home and sleep and leave me to settle my quarrel with Idemili, whose envy seeks to destroy me, so that his python many come to power...." (1974:192). One begins to wonder if Ezeulu is not just pushing his own war onto Ulu who is either not the powerful god he is expected to be or may not be willing to fight another "unjust war".

Generally, the role plays by Nwaka can be said to be that of an ideal opposition in an ideal democratic set up. Nwaka's stand is that of an opposition leader, in an ideal democracy, leading other opposition parties and Civil Rights groups, challenging the ruling party. Ideally the opposition should be upright, focused and unrelenting in its quest for good governance. But in Nigeria, the opposition is in absolute disarray, most of them are agents of the ruling party that are paid to disorganize the opposition group. Each one fighting his person cause of getting it him share of the "NationalCake", either to be appointed into the government or to be settled with millions of naira or contracts. As a result, the democracy in Nigeria is locked in deep crisis because of lack of credible opposition, which is one of the fundamentals or major ingredients of any stable civilian government. I wish to state here that if the opposition in Nigeria will be as resolute as Nwaka the democracy will go places not only in Africa but world over.

Similarly, in The Last Imam, Mallam Shuaibu turns out to be a staunch antagonist to Alhaji Usman. Mallam Shuaibu is described by the Emir of Bauchi as "a noble bastard half-brother" of Alhaji Usman's father's secret relationship with a slave girl before his birth. Shuaibu's speculations is that if their father had known about him, he, Shuaibu might have been the Imam not Alhaji Usman. He thereby hold Alhaji Usman in a level of admiration-hate attitude, while Alhaji Usman hold him in paternalistic disdain. In an internal monologue Alhaji Usman describes Mallam Shuaibu's education thus:

...he considered the Mallam's brand of Muslim Education inferior and useless for the deep communication with Allah...wherever they met he treated him with a sort of affectionate paternalism which concealed... disdain he felt for him. (1984:78-9).

Therefore, the mutual-disdain relationship metamorphoses into love-hate affairs and ultimately leads to Mallam Shuaibu supplanting Alhaji Usman as the Imam of Bauchi Emirate. In comparison with the situation in Nigeria Mallam Shuaibu can be said to be playing role of a good boy to the god-fathers. To them, competence is not an issue but what matters most to them is absolute loyalty to their wishes.

In a deliberate attempt to perfect their works, the two novelists present probably the best developed characters in the Nigerian novel-fiction, as Achebe himself subsumes that:

Ezeulu, the Chief character of Arrow of God, is a different kind of man from Okonkwo. He is an intellectual. He thinks about why things happen-he is a priest and his office requires this-so he goes into the roots of things and he's ready to accept change, intellectually. (1999:232).

Equally, in The Last Imam, the narrator describes Alhaji Usman as:

...the only man in the entire province among only a few in whole of Hausaland who could quote word by word, at any time, and provide translations for any text that had been written by Muslim theologians to every verse in the Holy Koran? He is also an "intellectual" like Ezeulu in Arrow of God. (Italics mine, 1984:8).

In another reference to the democratic crisis in Nigeria, the two heroes are accurate depiction of the leaders in Nigeria. All the leaders in power are highly educated in various fields of educational endeavors. Therefore, they, like Ezeulu and Alhaji Usman, manipulate the constitution or violet it tenants in order to feather their self-desires.

In both novels, the fatal flaws of the heroes lead to their tragic ends. Both lose the support of their various communities. Ironically, both Alhaji Usman, who resists change rigidly, and Ezeulu who seems to accept change, by sending his son to the Christian school, are both swept aside by the new forces.

Finally, it is my opinion that the novelists attempt to depict and interpret histories of what might have happened in their various societies, where people given responsibilities of leadership misuse the powers given to them at the detriment of the people they ought to serve. Thus, the two novels portray political or power tussle similar to what is obtain in the democratic set-up in Nigerian. Their attitudes of misuse of power is solely responsible for the crises the democratic structure in Nigeria is going through, issues such as election rigging, misuse of power by the ruling party, lack of credible opposition and imposition of incompetent persons in power are abound in the system. The tragic fall of the two heroes is a signal to the politicians that if those factors responsible to the raging crises in the hard earned democracy may not go far. What happened in Egypt, Tunisia and Libya and, still happening in Syria are enough signals to the politicians in Nigeria. 


\section{References}

Chinua, A. (1974). Arrow of God. London: Heinemann Ltd.

Gareth, G. "Language and Action in the novels of Chinua Achebe", in African Literature Today. No. 5. (ed), E. D. Jones. London: Heinemann Ltd.

Idris, M. (1994). "Trends in Northern Nigerian Novels in English: The Examples of Ibrahim Tahir, Zaynab Alkali and Abubakar Gimba”, an Unpublished M.A. Thesis Bayero University, Kano.

Zainab, I. A. (1998). “Islam in African Literature: A Study of Ibrahim Tahir's The Last Imam”, an Unpublished M. A. Thesis. Bayero University, Kano.

Nnolim, E. C. (1999). "Techniques and Meaning in Achebe's Arrow of God" in Approaches to the African Novel: Essay in Analysis. Owerri: Ibem Press Ltd.

Tahir, I. (1984). The Last Imam. London: Routledge and Kegan Paul Ltd.

Bamikunle, A. (2003:3-7). "The Novels of Chinua Achebe and Ibrahim Tahir”, (Rev), in Daily Times Saturday, July 12. 